\title{
Before Copernicus and Copernicus
}

by

Matjaž Vesel

Research Centre of the Slovenian

Academy of Sciences and Arts

matjaz.vesel@zrc-sazu.si 


\begin{abstract}
A discussion of Before Copernicus: The Cultures and Contexts of Scientific Learning in the Fifteenth Century edited by Rivka Feldhay and F. Jamil Ragep.

About the Author

MATJAŽ VESEL is a senior research fellow at the Institute of Philosophy in the Research Centre of the Slovenian Academy of Sciences and Arts (Ljubljana, Slovenia). His research focuses mostly on historical epistemology in the period from the late Middle Ages to Newton. He has published monographs on Nicholas Cusanus, Nicolaus Copernicus, and Galileo Galilei, as well as numerous articles on medieval and early modern science and philosophy. $\mathrm{He}$ is also the editor of the series Historia scientiae (Založba ZRC, the publishing unit of RC SASA), dedicated to publishing scholarly translations of the key texts from the history of human knowledge (scientia).
\end{abstract}




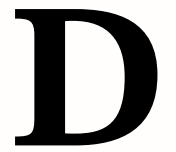

espite extensive and increasingly nuanced scholarly research, the work of Nicholas Copernicus, one of the most iconic names in the history of human thought, is still controversial. Before addressing some of the controversies and Before Copernicus [Feldhay and Ragep 2017] in this context, allow me to note some fairly uncontroversial, basic facts about his life and astronomical work.

Copernicus, who was born in Torun in 1473 , enrolled as a student of liberal arts at the University of Cracow in 1491, which he left without a degree in 1495. In 1496, he moved to the University of Bologna to study canon and civil law. In 1500 , he briefly visited Rome and then returned to his native Warmia. Shortly after that, in 1501, he returned to Italy, this time to the University of Padua, where he was supposed to study medicine. He was awarded a doctorate in canon law from the University of Ferrara in 1503. Upon returning home, he started working as his uncle's physician and subsequently also as a church administrator. Sometime around 1510 (before 1514 and possibly as early as 1508), he drafted his earliest attempt at a heliocentric, geokinetic astronomy and cosmology in a text later known as De hypothesibus motuum caelestium a se constitutis commentariolus and referred to in short as the Commentariolus. This text presumably circulated among his friends but was not published during his lifetime. His next astronomical text was the very short (semi-) private Letter to Werner. Having been persuaded by Rheticus and some other friends, Copernicus finally published his major work $D e$ revolutionibus orbium coelestium in 1543 . He died in the same year.

The aspects of his work that are still debated are many and, due to the difficult, sometimes technical subject matter and substantial scholarly output, tend to be very nuanced and sophisticated. The famous Copernican question is really a bundle of different but interrelated questions. The more general ones, such as Was there really such an event as the Copernican revolution?, clearly depend on how we understand the concept of "science" (to put it anachronistically for the sake of brevity) and its multifaceted continuous transformations, and-no less importantly—on how well we understand Copernicus' immediate or less immediate "scientific" context, against which his achievements and contributions are to be assessed. This naturally leads to an examination of more specific details of his work: What exactly was the 
question that he was trying to answer? How, why, and when did he become a Copernican? What is the nature of the orbs mentioned in the title of his De revolutionibus orbium caelestium? Are his astronomical models the result of an independent development in Western thought or did he borrow them from his Islamic predecessors? These are just a few examples. It is generally understood, first, that these and other questions are in themselves very complex and divisible into myriad sub-questions that demand studies of considerable historical and epistemological breadth, length, and depth; and second, that sometimes seemingly insignificant details can turn the whole narrative completely upside down, since, as is usual in such complex matters, the whole depends on its parts as much as the parts depend on the whole. The aim of Before Copernicus is to address some of the above-mentioned issues by examining Copernicus' intellectual and social background. The book is divided into three parts:

Part 1 covers Copernicus' 15th-century European social and political context;

Part 2 is dedicated to his 15 th-century European intellectual and scientific context; and

Part 3 explores the multicultural astronomical background to the Copernican revolution.

Although the book, true to its title, focuses on the period before Copernicus, i.e., on the "long fifteenth century", ${ }^{1}$ its authors keep one eye on the value of this period for understanding Copernicus' work, especially his Commentariolus, which is set as the endpoint of the discussion.

With this in mind, I will divide my review into two sections. In the first, I will summarize the introduction, which sets the stage and defines the main coordinates of the discussions with several important "observations" (the editors' term) and conclusions. I will then attempt to summarize the main points and the most important results of each chapter. While I, together with the editors and contributors to the book, believe that Copernicus' work-or any other work of any significance, for that matter-can be fully appreciated only when set within a sufficiently long as well as adequately studied historical context, I will pay much closer attention to the chapters and chapter-sections that discuss issues that are in my view "closer" to Copernicus and, therefore, more relevant to an understanding of his Commentariolus. In

1 The interval from the mid-14th century to roughly 1525 , according to Christopher Celenza [17-18]. 
the second section of my review, I will provide a critical appraisal of the book with special emphasis on the question of how the book as a whole and each of the chapters succeed in making the genesis and nature of Copernicus' Commentariolus (and in some cases De revolutionibus) more understandable. At the same time, I will point out some conclusions that I find questionable and suggest alternative interpretations. I will also suggest what I believe still needs to be done to advance our understanding of Copernicus' astronomy and cosmology.

\section{Summary}

1.1 The introduction Rivka Feldhay and Jamil Ragep, the editors of the book and the authors of its introduction, explain the need for an examination of Copernicus' social and intellectual background by the fact that it is little understood. According to their outline of the most important issues discussed during the last half century (or so) of Copernican scholarship, he has sometimes been portrayed as a lone genius without history and without context. This changed with Thomas Kuhn's The Copernican Revolution and his thesis about the crisis that prompted the revolution. Kuhn did not manage, however, to explain the exact nature of this crisis, which

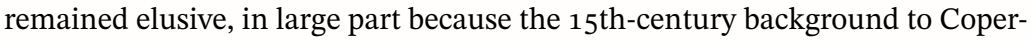
nicus was and remains to a large extent terra incognita. [3]

A major step forward was taken by Otto Neugebauer, who showed how much the mathematical details of Copernicus' work are connected to both the "Western" tradition and, crucially, the "Eastern", Islamic tradition.

In continuing Neugebauer's work, Noel Swerdlow arrived at even more important conclusions. His detailed analysis of the Commentariolus brought to light more evidence of Copernicus' debt to Islamic astronomers. Copernicus' mathematical models, which were supposed to solve the so-called "equant problem" (among other things), were very similar or identical to those of his Islamic predecessors. ${ }^{2}$ Swerdlow stressed the importance of Copernicus' adherence to physical astronomy, i.e., to the astronomy of real, solid orbs. And finally, he voiced speculation about Copernicus' path to heliocentrism. He

2 To the observer stationed on the motionless Earth at the center of the cosmos, the five planets along with the Sun and Moon exhibit nonuniform velocity during their courses through the zodiacal band. Ptolemy tried to solve this problem with the concept of the equant, a mathematically established point or punctum equans about which each body was supposed to move uniformly. This solution was deemed unsatisfactory and problematic. 
posited that Copernicus had come to his heliocentric cosmology by a technical route, that Copernicus turned to heliocentrism because he believed that the planets are carried around by solid spheres and because he adhered to the principle of the uniform and circular motion of the heavenly spheres. Copernicus' search for an alternative that avoided Ptolemy's violation of the second principle (the equant problem) led him to a "Tychonic" cosmography that had the Sun moving about the Earth while being more or less at the center of the orbs of the retrograding planets. Since, in this system, the solid orbs of the Sun and Mars intersect, Swerdlow speculated that Copernicus opted for one with a static Sun and a moving Earth in which all the orbs were discretely nested.

Swerdlow's publication incited discussion of Copernicus' belief in solid spheres and his debt to his Islamic predecessors for his mathematical models. Critics of Swerdlow's reconstruction, who include Feldhay and Ragep, as we shall see later, claimed that there must be "more to this monumental cosmological shift than a strictly mathematical/astronomical explanation" and that there "were certainly other ways to deal with the problem of the equant and other Ptolemaic violations" [4]. Al-Shātị, for example, from whom Copernicus apparently borrowed extensively in the Commentariolus, dealt with the Ptolemaic difficulties while retaining a geocentric cosmology. There have indeed been other proposals that pretend to provide "the missing cause or motivation" for Copernicus. Mario Di Bono drew attention to the Paduan Aristotelians, Andre Goddu to the Cracowian Aristotelians, and Robert S. Westman to the astrological "crisis" caused by questions about the planetary order. But Feldhay and Ragep are uncomfortable with the predominant attempts to reduce the Copernican question "to one of finding the univocal explanation that somehow supersedes all others" and with the fact that "the most recent discussions of Copernicus have taken a Eurocentric turn, with the question of cross-cultural influence mostly set aside" [5]; and so they have assembled scholars to discuss the background to Copernicus in a multicultural and multidisciplinary way. With the Commentariolus as the endpoint, these discussions were guided by a set of observations from which several conclusions were reached. Let me cite these seven observations in full here:

1. Copernicus' stated purpose in the Commentariolus is to find "a more reasonable model composed of circles...from which every apparent irregularity would follow while everything in itself moved uniformly, just as the principle of perfect motion requires”. 
2. Copernicus does not refer in the Commentariolus to the "marvelous symmetry" brought on by his new ordering of the planets, as he does in De revolutionibus. Although one must be cautious when speaking of motivation, it is curious that Copernicus does not explicitly put forth in the Commentariolus what is perhaps his most compelling argument.

3. Copernicus' models (taking into account both the Commentariolus and De revolutionibus) contain both eccentrics and epicycles.

4. There is strong evidence that Copernicus adheres to solid-sphere astronomy.

5. There is no indication that Copernicus ever resorted to a strictly Aristotelian, Averroist, Bițrūjian, or Paduan "homocentric" astronomy. Copernicus does insist on a single center for his main orbs and otherwise uses only epicycles in the Commentariolus, whereas he uses eccentrics with their multiple centers in his De revolutionibus.

6. The number of similarities between the planetary models in the Commentariolus and those advanced by Ibn al-Shātir (14th-century Damascus) is significant.

7. Discussions of the possibility that the Earth is in motion can be found in both Islam and Christendom prior to Copernicus. [5-6]

While Feldhay and Ragep admit that "any number of conclusions may be drawn from these observations" [6], they propose the following:

(1) Copernicus' initial motivation was to address the violation of the principle of perfect motion, that is, of its uniformity. The symmetria of the cosmos achieved by the heliocentric ordering of the planets in De revolutionibus was post hoc. They are, therefore, not convinced by Goldstein [2002] and Westman [2013] that the ordering of the planets was a motivating factor (from 1 and 2).

(2) Copernicus' work falls within the tradition of Ptolemy's Almagest and Planetary Hypotheses, the hay'a-tradition of Islamic astronomy,

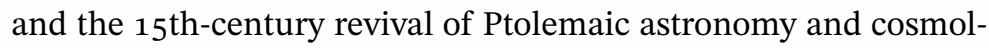
ogy as found in Peurbach's Theoricae novae planetarum and in Regiomontanus' Epitome of the Almagest (from 3, 4, and 5).

(3) In his early career, Copernicus was concerned with some kind of quasi-homocentrism (from 5).

(4) He was significantly influenced by post-1200 Islamic astronomy (from 6). The existence of a longstanding criticism of Ptolemy and alternative models that were developed within the geocentric cosmology highlight, however,

that it was not necessary for Copernicus to make his momentous transformation in order to satisfy his stated goal of a cosmography with 
uniform circular orbs. It thus seems that there were aspects of Copernicus' intellectual and cultural context that led him to his decision to put the Earth in motion. [6-7]

(5) Copernicus may have been aware of, or influenced by, discussions about the motion of the Earth in prior Christian and/or Islamic traditions (from 7).

Feldhay and Ragep's point of departure was their dissatisfaction with Swerdlow's technical reconstruction of Copernicus' conversion to heliocentrism. Copernicus might, they reaffirm,

have fulfilled his stated goal of a reformed astronomy with uniform, circular motions within a geocentric framework. This latter approach was, after all, the one that a number of Islamic astronomers had already employed to a large extent. [7]

Accordingly, they are not convinced that the response to the Copernican question is "through one correct derivation of a model that necessarily led to a coherent and true astronomical-cosmological picture" [8]. Instead, they see Copernicus' system as a result of many practices

that included attempts to deal, mathematically, with violations of physics found in Ptolemy's models, discussions of the relation of natural philosophy and mathematics, and epistemological forays into the "true" cosmology and the human capacity to discover it. [8]

They likewise believe that $15^{\text {th-century astronomy was }}$

the outcome of multiple transformations along different paths that crystallized in the work of Copernicus into some kind of coherent whole that differed enough from the preceding astronomical discourse to open the door to additional, enhanced transformations. [8]

1.2 Part 1. Social and political contexts Christopher Celenza ("What Did It Mean to Live in the Long Fifteenth Century?" [17-28] ) discusses some characteristic features of the 15 th century that could have shaped Copernicus' world. Celenza reflects on the political life of the time and points out that in order to find some personal safety as well as to advance their intellectual activities, the scholars of Copernicus' period sought personal patronage. Celenza sees Copernicus as a member of the group of traveling scholars in search of patronage and briefly examines his studies at the universities of Bologna and Padua, stressing their "secularism", that is, their lack of an organic link between concern with the arts and theology, on the one hand, and their link to Italian humanism, on the other, where humanism meant 
a willingness to question authority....Given this situation, Copernicus' willingness to entertain divergent techniques (like the Tūsī-couple) and possibly revolutionary viewpoints (like heliocentrism) becomes more understandable. [20]

Celenza also shows that in Copernicus' time intellectual elites still believed in supernatural powers.

The most important section of the chapter, however, is perhaps the one dedicated to the way in which information was gathered and transmitted. One of the characteristics of the $15^{\text {th }}$ century was a collaborative approach to knowledge. There were many different varieties of reading and writing practices and

a number of them make it likely that [Copernicus] may well have come across a theory like the Țūsī-couple without feeling the characteristically modern need to record precisely where, when, and in what format he encountered it. [28]

Nancy Bisaha ("European Cross-Cultural Contexts before Copernicus" [29-41]) focuses on the political realities relevant to the transmission of knowledge. Her basic question is

[W] hy did Copernicus and his contemporaries say nothing about recent Islamic astronomers if they were so heavily indebted to them?... How and why did such astronomical knowledge travel great distances in the early modern era, only to have its origins vanish so effectively that scholars did not discover them until the last few decades? [29]

She draws a picture of the complex, multifaceted relations between Latin Europe, the Ottoman Empire, and Byzantine refugees in Europe. The exchanges that took place among European, Asian, and Byzantine scholars were characterized by connections and tensions at the same time. Muslims, for instance, "were extremely wary of travelling in Christian Europe, with the exception of Venice, throughout the period" [32]. Her key examples that illustrate this situation are the books Europe and Asia, often printed together and read as one piece called the Cosmographia, written by Aeneas Silvius Piccolomini, Pope Pius II (1458-1464). These two texts reflect the crystallization of a European identity vis-à-vis the perception of Asia as "the other". Bisaha considers three possible explanations of why Copernicus did not acknowledge his borrowings from Islamic astronomy:

(1) The Islamic origins of Copernicus' ideas were obscured at some point by Greek refugees, who

found the provenance a sensitive subject given their adamant calls for crusade and the rhetoric of Ottoman barbarism that was so fashionable in western Europe. [40] 
(2) "Copernicus knew the origins and chose not to note them for fear of unpleasantness or a harsh reaction from the papacy" [40]. and

(3) This lack of provenance could be "simply due to an innocent omission at some point in the transmission" [40].

Bisaha points out one common denominator that emerges despite all of this uncertainty. These new ideas

travelled westward and were used, but they were changed or cloaked consciously or unconsciously, perhaps to make them fit with the growing belief among Europeans that their current scholarship had surpassed that of the East. [41]

1.3 Part 2. Intellectual and scientific contexts With Edith Dudley Sylla's chapter ("The Status of Astronomy as a Science in Fifteenth-Century Cracow: Ibn al-Haytham, Peurbach, and Copernicus" [45-78] ), we focus more closely on Copernicus; more exactly, on his Commentariolus and its background, which can, according to Sylla, be found in Copernicus' years as a student in Cracow (1491-1495). Two eminent teachers, John of Głogów and Albert de Brudzewo, were active there at that time. Głogów probably lectured on Aristotle's Posterior Analytics and, in 1499, when Copernicus had already left Cracow for Bologna, published a commentary thereon. He also wrote a commentary on Sacrobosco's Sphere. Brudzewo wrote a commentary on the most popular and progressive textbook of the day in astronomy, Peurbach's Theoricae novae planetarum, which was also printed after Copernicus' departure. It is very likely, however, that Copernicus was familiar with all three texts either through manuscripts or through lectures (not necessarily by Głogów and/or Brudzewo) based on these manuscripts.

Sylla develops two lines of investigation. One is the development of the theoretical and narrative, i.e., non-demonstrative, astronomy that was intended as introductory and is found in the so-called theorica-tradition. This was physical astronomy, an astronomy that proposed the physical bodies that might lie behind the observed motions described mathematically in Ptolemaic astronomy. She links Ibn al-Haytham's On the Configuration of the World (transmitted to Latin-speaking Europe at the latest by the end of the 13th century) and the hay'a-tradition of Islamic astronomy with the European tradition of theorica-astronomy, and this in turn with Peurbach's Theoricae novae planetarum, and the Theoricae novae with Copernicus' Commentariolus. The second line of her investigation concerns the status of astronomy as a science as this was understood in the commentaries on Aristotle's Posterior Analytics. She approaches this question through the 
medieval opposition of antiqui versus moderni and, closer to Copernicus, by an analysis of the above-mentioned texts by John of Głogów and Albert de Brudzewo.

Copernicus' Commentariolus lies firmly in the same tradition as Peuerbach's Theoricae novae planetarum. It is "theoretical rather than practical, narrative rather than demonstrative, and based on the assertion of hypotheses or principles" [45]. The Commentariolus mirrors the Theoricae in starting with a statement of principles. In Copernicus' work these principles are called postulates (petitiones) and in Peurbach's work they are the theoricae (figures) themselves together with their descriptions of planetary orbs. Copernicus' petitiones represent

hypotheses derived from experience, which are to be accepted as true, even though they could be wrong given that astronomy is a science still in the process of development. [49]

The orbs of the Theoricae (three-dimensional, three-part spherical shells) are the identifying DNA of the configuration that it shares with Ibn alHaytham's On the Configuration of the World. Ibn al-Haytham and the Islamic hay'a-tradition understood these orbs as rigid, not fluid bodies. They included deferents and epicycles, and, while the planets are held tightly in place, they can rotate uniformly but without ever exceeding the place or cavity they are in. Moreover, these orbs spin. Brudzewo's commentary on Peurbach's Theoricae novae establishes what he understood to be the proper principles of Theoricae novae. All five principles are of a physical rather than mathematical nature, such as, for instance, the second: "Of any simple body there is only one simple motion proper to it naturally". These "principles have a relation to Peurbach's Theoricae novae planetarum similar to the relation of Copernicus' petitiones to his Commentariolus" and are ultimately derived "from thinking about observations and how they could be explained by underlying reality" [53]. This format, however, was not unique to theoretical astronomy. Many scholastic philosophers before Brudzewo

put their theories or parts of their theories into a structure in which there are suppositions, principles, or premises (i.e., hypotheses) on which conclusions are based. [54]

These principles are usually physical rather than mathematical and are held to be derived from experience.

Although Sylla believes that the predominant influence on the Commentariolus was that of the conception of astronomy in the Theoricae novae planetarum, she thinks that 
the background of Aristotelian philosophy at Cracow also helps to explain why Copernicus might have proposed a new configuration of the world in the Commentariolus. [6o]

This leads her to discuss the concepts of science in general and astronomy in particular as formulated in different commentaries on Aristotle's Posterior Analytics. She situates the discussion within the medieval Aristotelian opposition between a conservative via antiqua and a progressive via moderna, and argues that

the conception of astronomy as a science that Copernicus encountered as a student at Cracow University, the one reflected in the Commentariolus, was closer to the attitudes of the moderni than to those of the antiqui. [59]

This is confirmed by Głogów's texts (Commentary on Sacrobosco's On the Sphere of the World and Commentary on the Posterior Analytics), which are consistent with the views of the moderni. In his Commentary on the Posterior Analytics, Głogów, for example, in answering the question of whether it is possible to know something de novo, opposes Plato in claiming that we can have scientific knowledge and that it can be new rather than always something that we knew previously but forgot. One of the important features of his commentary on On the Sphere is a distinction between what is mathematical (hence imaginary, hence dependent on human thought) in astronomical theories and what is physical. The same is the case with Brudzewo's Commentary on the Theoricae novae planetarum. He, too, has a clear conception of astronomy as partly physical and partly mathematical. He repeatedly differentiates between physical orbs and mathematical/imaginary circles. Brudzewo argues that astronomers are not to dispute the basic principle of astronomy, that is, the uniform circular rotation of the celestial bodies. He also claims explicitly that the equant is not a physical thing since there is no corresponding aetherial sphere in the heavens. Despite that, astronomers used it for the purposes of practical astronomy (i.e., astrology) to support prognostications concerning the effects of the heavenly bodies on Earth.

What, then, did Copernicus learn while studying in Cracow? The main thing was Peurbach's Theoricae novae planetarum, which served as a model for the status of astronomy as a science. Copernicus was exposed to the idea of theoretical (not demonstrative) astronomy according to which the astronomer "can start by stating principles or postulates upon which the following exposition will be based" [53]. This had certain consequences for astronomers. Knowing that "principles are not proved and that the processes by which they are arrived at are not logically rigorous" [54], astronomers could be led to think about a reformation of principles. And this, according to Sylla, is 
exactly what Copernicus says at the very beginning of the Commentariolus before he lists his seven postulates (petitiones).

Since Copernicus, like the authors of theoricae planetarum, starts with physical principles, he must have "conceived his research program within the theorica planetarum genre". Copernicus also learned "that astronomy was both mathematical and physical and that, although it had many real achievements, it might still be improved by new insight into the hidden physical structures behind the appearances" [55]. The physical side of astronomy was represented in real three-dimensional orbs; the mathematical side was represented in theoricae/figures that were two-dimensional geometrical circles and lines. These figures were understood as products of mathematical constructions or human imagination and not as real things existing in the external world. The task of physical astronomy was to find physical bodies that might lie behind the observed motions described mathematically in Ptolemaic astronomy. In Copernicus' period, this task of finding physical configurations consistent with mathematical regularities had not been completed. There was, therefore, a constant need for new and better physical hypotheses, better physical configurations. Astronomy was, therefore, conceived as a progressive scientific discipline in which principles were "derived a posteriori from experience and hence could be received from new or added experience" [59].

Michael Shank ("Regiomontanus and Astronomical Controversy in the Background of Copernicus" [79-109]) discusses the life of the most important and advanced astronomer before Copernicus, Johannes Regiomontanus, his approach-or better, approaches, as we shall see-to astronomy, and his impact on Copernicus. Two important personalities had a strong influence on Regiomontanus' career. One was the astronomer and humanist Georg Peurbach, author of the Theoricae novae planetarum, with whom Regiomontanus worked in Vienna. The second was Basilios Bessarion, a Greek émigré, originally a Byzantine orthodox and a student of the Platonist George Gemistos Pletho, who became a cardinal of the Roman Catholic Church and was instrumental in procuring the Epitome of the Almagest, the book that Copernicus preferred over the Almagest.

One of Regiomontanus' earliest astronomical manuscripts is a copy of Peurbach's lectures of 1454 on his Theoricae novae planetarum at the Bürgerschule in Vienna. The "New (novae)" in its title signaled the fact that it presented the real, physical configurations and motion of the spheres, as opposed to merely mathematical ones. When Regiomontanus edited it for the first time in 1474, partial spheres of the planetary models, being physical, were filled 
in with black ink or striking colors, while the purely geometrical diagrams were thin black-on-white lines. Regiomontanus' astronomical interest did not stop with his mentor's work. While in Vienna, he also studied Henry of Langenstein's De reprobatione ecentricorum et epicyclorum (1364), which stimulated his openness to homocentric possibilities. He later formulated similar proposals and objections when criticizing Ptolemy's approach in the Almagest. Regiomontanus was also aware of the earlier homocentric system of al-Dīn al-Bitrūjī's De motibus celorum (translated into Latin from the Arabic in 1217 by Michael Scot) and his unorthodox arrangement of the inferior planets according to their synodic period: Venus above the Sun and Mercury below it.

In 1461, Regiomontanus left Vienna for good in the company of Cardinal Bessarion. His association with Bessarion was connected with a long controversy between Bessarion and another Greek émigré in Italy, George of Trebizond (1396-1472). George had translated Ptolemy's Almagest from Greek into Latin in order to replace Cremona's 12th-century Latin translation from the Arabic but his new translation and the commentary were judged less than satisfactory. The commentary itself was full of errors and Bessarion was angered by George's attacks on Theon of Alexandria's commentary, which Bessarion recommended as a guide. The relationship of the two men deteriorated even further for philosophical reasons. In 1455, George published Comparatio philosophorum Aristotelis et Platonis, an apologia of Aristotle and an attack on Plato and his followers, especially Pletho and Bessarion. During his diplomatic visit to Vienna (1460-1461), Bessarion convinced Peurbach and Regiomontanus to write an epitome of the Almagest that would displace George's work on the subject. Peurbach started, finished half of the Epitome of the Almagest, and then died suddenly in April 1461. When Bessarion left for Italy, Regiomontanus accompanied him and remained a member of the Cardinal's familia, improving his Greek, revising Peurbach's first half, and writing the remainder of the Epitome. He completed the task in about 1462. The Epitome, however, remained a manuscript with limited circulation which became wider after it was printed in Venice in 1496, the year of Copernicus' arrival in Bologna.

The Epitome is a detailed, sometimes updated, condensed, and clearer exposition of Ptolemy's Almagest. Its format follows the general structure of the Almagest but has a more Euclidean layout. Along the lines of the Almagestum parvum, each book is organized into propositions, many followed by proofs. It sometimes comments on post-Ptolemaic developments. On the other hand, the summary of book 1-the most natural-philosophical part of 
the Almagest-leaves the discussion in the second century and says nothing about the late-medieval natural-philosophical debates about the rotation of the Earth. Among the problems of Ptolemy's astronomy, the Epitome notes the problems with its lunar theory. Another intriguing feature is the proof of the equivalence of the epicyclic and eccentric models for the second anomaly of the planets in book 12.

After finishing the Epitome, Regiomontanus dived into Bessarion's library, which contained 1,000 Greek and Latin manuscripts and included several Greek Almagests, Proclus' Hypotyposis astronomicarum positionum, Theon of Alexandria's Commentary on the Almagest, and Theon of Smyrna's Mathematical Knowledge Useful for Reading Plato. It is worth noting that Proclus, in his Hypotyposis astronomicarum positionum, refers to the proof of the equivalence between the eccentric and epicyclic models.

In 1463, Regiomontanus entered into a correspondence with the Italian astronomer Giovanni Bianchini that demonstrates his mathematical skills, his dissatisfactions with the existing tables and mathematical models, and his expectations of consistency in physical and mathematical predictions, all being consistent with his hopes for the advent of a homocentric astronomy. His Defensio Theonis contra Georgium Trapezuntium, a work intended to destroy George's Commentary on the Almagest, reveals Regiomontanus' desire for an astronomy that would integrate physical and mathematical considerations. The Defensio shows his conflicting sympathies: Ptolemaic, homocentric, and Peurbachian. Regiomontanus "faced a trilemma that left unresolved the tensions between the pros and cons of his three options" [97]. In this text, Regiomontanus also treats the order of the planets as an unsolved problem and illustrates it by citing the different positions taken by Ptolemy, Martianus Capella, Geber, Biṭūjī, and others:

Copernicus would work on precisely this problem and was thrilled to see that reordering the planets (and the Earth) around the mean Sun gave their spheres a necessary order. [97]

After some time spent in Hungary, Regiomontanus moved to Nuremberg and set up the first printing press devoted primarily to the mathematical sciences.

What about Copernicus' use of Regiomontanus' work? Copernicus owned and used several works by Regiomontanus, especially his Epitome of the Almagest, in many ways. The earliest traces of the language of the Epitome are in Copernicus' "computations of planetary spheres that preceded the conversion to heliocentrism before the Commentariolus" [102] but they also pervade the detailed quantitative implementation of his new theory in his 
De revolutionibus. Another point of considerable significance is that the Epitome

stressed some of the unfinished business of astronomy, such as the order of the Sun and the inferior planets, to which Regiomontanus explicitly ascribed "no certainty" (nulla certitudine) at the beginning of Book 9. [102]

But the most important impact of the Epitome on Copernicus is that it stands behind Copernicus' move to his new astronomical system, which placed not the physical Sun but the mean Sun at the center of the Earth's orb. [102]

Another significant sign of Copernicus' faith in the Epitome is his

following Regiomontanus in not undertaking to derive his astronomical models themselves from observations. Both men believed that, whatever their problems from a physical point of view, Ptolemy's models were basically adequate to their task from the geometrical and predictive points of view. [108]

Rivka Feldhay and Raz Chen-Morris ("Framing the Appearances in the Fifteenth Century: Alberti, Cusanus, Regiomontanus, and Copernicus" [110-140]) analyze different conceptualizations of appearances (phaeno-

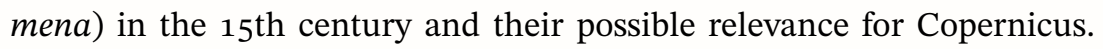
In an often overlooked passage of the Commentariolus, Copernicus denounces the philosophers' defense of the immobility of the Earth as being founded upon appearances; and in his later De revolutionibus, he explains the phenomena of the movements in the heavens, such as the risings and settings of the zodiacal signs and the fixed stars, the stations of the planets and their retrogradations, by the motions of the Earth "which the planets borrow for their own appearances" [Rosen 1992, 18]. Copernicus' claim, in other words, is that the immobility of the Earth, one of our most basic visual experiences, is just apparent (visible but not true), while at same time he affirms that the mobility of the Earth-not experienced, invisible-is a reality that explains the apparent motions of the stars and the planets. How could he have come to such a conclusion? Or, to put it differently, "[W] hat enabled the competent, cautious astronomer Nicholas Copernicus to embrace the idea of an invisibly moving Earth?" [114]. In line with the introduction, Feldhay and Chen-Morris are critical of Swerdlow's technical reconstruction of Copernicus' path to heliocentrism. Why did Copernicus, they ask, find a heliocentric conversion of an eccentric model of the second anomaly for the inferior planets attractive (i.e., the element, according to Swerdlow, that is crucial in the transition to a heliocentric cosmology), whereas Regiomontanus simply stopped short of all that?

If Regiomontanus was very likely aware of the possibility of a heliocentric conversion, as Swerdlow maintains, one may rightly assume that there was 
no mathematical-technical reason for him to reject it. Likewise, there was no mathematical-technical reason for Copernicus to adopt it and infer further the motion of the Earth. [114]

There is "no clear answer to such a question" [114], but Copernicus' claim about his engagement with something "beyond appearance" (praeter apparentia) encourages an investigation of the conceptualizations of the relationship of appearances to their "beyond" in 15th-century Europe.

Feldhay and Chen-Morris search for an answer to their question in the works and practices of Leon Battista Alberti (1404-1472), Nicholas of Cusa (i.e., Cusanus) (1401-1464), and Johannes Regiomontanus (1436-1476). These three important figures, plus Paolo Toscanelli (1397-1482), were connected through a social network: Regiomontanus, Toscanelli, and Cusanus even met personally at Bessarion's villa in Rome, while Alberti, a member of the papal curia since 1420 , was a constant visitor to the villa-which

testifies to the existence in Italy of a cultural field in which mathematicians...as well as philosopher-theologians like Cusanus took a position and articulated their critique of each others' views. [113]

Copernicus probably acquainted himself with this field when he came to Bologna in 1496, and "this field may have inspired his daring to experiment with the idea of a moving Earth" [114].

Alberti's De pictura (1435-1436) laid the foundations for the theory of artificial perspective. Feldhay and Chen-Morris see it

as an ambitious project to broaden the scope of the visible that challenged the accepted boundaries between the natural and the artificial. [113-114]

His enterprise concerned the question of how a

sensible and mathematical, yet invisible, grid of perspective constitutes the spatial relationships on the surface of the painting and offers a new perception of beauty radiating from things represented to the observer's understanding. [113]

According to Alberti, the artist does not imitate and represent nature itself but aims at the forms of beauty that are "lurking beyond the phenomena and concealed behind them" [116]. Painting on a two-dimensional surface brings forth Alberti's ideal of beauty, such as the "symmetry" and "harmony" between the different parts of the painting.

The desire to see what is beyond appearances found similar expression in the theologian Cusanus, who elaborated Alberti's project by different means. In his major works, from De docta ignorantia to De possest, Cusanus attempted to explain how one can "view things that were invisible before" 
and how the mind can be presented "with a vivid image of the invisible unification of opposites (oppositorum coincidentia)" [117], i.e., God. One of the methods that he used for such purposes was speculative mathematics, with which he tried to solve the quadrature of the circle. He wrote 11 mathematical treatises dedicated to the quadrature and corresponded about it with fellow mathematicians, philosophers, and theologians. He tried to find a "visible" geometrical point that would represent the "invisible" coincidence of opposites (i.e., an intellectual vision of God). According to Feldhay and Chen-Morris, Cusanus' writings on quadrature

engaged the best European mathematicians of the period-whom he personally knew-in a conversation about the quadrature across disciplinary and professional boundaries. The echoes of this conversation were likely to have reached Copernicus in Bologna and Ferrara some decades after they took place among Cusanus, Regiomontanus, Toscanelli, and perhaps even Alberti. [121]

For Cusanus, mathematics was not just a method but a model used in the constitution of the world for human understanding. His statement that

the intellect is to truth like the polygon is to the circle in which it is inscribed [reveals] the motivation behind his investigations of the quadrature problem, namely to observe critically, from an imagined divine point of view, the limitations of the human intellect. Applying the results of his investigations to the theological realm, Cusanus broadened Alberti's discourse on the visibleinvisible relationship and provided new kinds of legitimization for naturalizing the invisible within the discourse on human knowledge. [113]

Cusanus' conceptualizations of the mathematical conclusions in theological terms belong to the history of "invisibles" "that may have made possible Copernicus' later leap into a cosmological invisible such as the motion of the Earth" [121].

Cusanus' preoccupation with mathematical procedures came to the notice of Johannes Regiomontanus, via the Italian mathematician Paolo Toscanelli, a common friend. Regiomontanus wrote a series of texts on the quadrature of the circle, criticizing Cusanus' “speculations”. Regiomontanus' distance from Alberti's and Cusanus' projects of representing invisible and abstract entities in a visual form is also manifest in his views on the required astronomical reform and the place of observation within it. Regiomontanus constantly complained of the erroneous observations of his predecessors and put his trust in those astronomers ready to make new observations and compare them with sound and good calculations. He himself barely bothered to improve the situation. 
What is the stance of traditional astronomy regarding appearances? Since antiquity, astronomy had been based on what the astronomer saw and appearances were assumed to be valid and authentic regardless of the specific theory suggested.

All there was to be explained was in front of the astronomer's eyes, and these explanations were supplied under the assumption of order. [134]

Appearances are true; they are not illusions and have to be explained in accordance with the assumption that the motions of the heavenly bodies are by nature uniform and circular. For a static observer situated at the center of the universe, the planets really do retrograde. The task of the astronomer is to find

a system of circles to explain why the planets move in such peculiar ways without damaging the cognitive value of the observer's ocular experience. [134] Either an eccentric circle or an epicycle would do the job but they are both "calculated in relationship to the point of view of an observer situated at the center of the universe" [135]. This dependence of mathematical theory on visual experience is clear from Ptolemy's presentation of the equant as an explanation of the anomalies of the planets. The equant is a point that is not directly related to the observer but to a "point bisecting the line joining the center of the ecliptic and the point about which the ecliptic has its uniform motion" [135]. Ptolemy admits that this procedure is not taken from any apparent principle. It is without proof: its only justification is that it is in agreement with the phenomena. For Ptolemy, the coherence of the models is less important than saving visual experience, which has to be realized in accordance with the more basic principle of preserving uniform circular motion without exception. The specific feature of the equant is that it "implies that the point from which planetary motions can be viewed as uniform is an imaginary point unrelated to the position of the observer" [135].

But, while the eccentric spheres are physically real and calculated with regard to the observer's central position, the equant is, according to Peurbach, based on an imagined circle around the equant point, i.e., around the point on the line of the apogee as far from the center of its orb as this center is distant from the center of the world. The basic characteristic of traditional astronomy, upheld also by Regiomontanus, was that it assumed the reality of celestial appearances. There is no doubt about what one sees. Astronomers apply invisible spheres and circles only to substantiate the authenticity of their observations. Alberti and Cusanus, however, challenged this traditional conception of astronomy on several levels by probing the 
demarcation between the phenomenal realm and the realm of invisible structures:

(1) the position of the observer is not predetermined and static; appearances are relative to one's point of view, and

(2) it is possible "to peer beyond appearances to gauge invisible structures and entities through the use of different kinds of devices" [135-136].

"These two notions", claim the authors, "may have shaped Copernicus' propensity to accept the invisible motion of the Earth as a basic principle of his system" [136]. In both the Commentariolus and De revolutionibus, Copernicus continuously points out that appearances misled astronomers into ascribing the wrong motions to the celestial bodies and that one should adopt a critical attitude toward the testimony of the eyes. The interpretation of visual experience has to take into account the position(s) of the observer's own actual viewpoint (no longer central) and his or her location within the entire universe (there are constant changes due to the Earth's motions).

Going beyond one's local and immediate point of view entailed the realization that appearances are a function of the observer's location. The new forms of visibility proposed by Alberti's techniques of perspective and by Cusanus' geometrical visualizations were part of a more general cultural reassessment of the role of perception in the cognitive process leading to knowledge. This role had special relevance to the epistemological status of astronomy, the observational science par excellence.... The core of Copernicus' argument is the limits of sense perception and the need to surpass them. [140]

Whether the Earth moves or not

cannot be derived from one's sense experience, as these phenomena presuppose the observer's point of view. By calculating the observer's position, Copernicus can transcend visual experience and gauge a new invisible point of view from where a new picture of the universe is revealed. These calculations incorporate novel mathematical techniques coming from the East, yet Copernicus mobilizes these techniques to answer the challenges that Alberti's artificial perspective and Cusanus' theological speculations offered to visual experience in the preceding century. [140]

1.4 Part 3. Copernicus' multicultural background To open part 3, Sally Ragep ("Fifteenth-Century Astronomy in the Islamic World" [143-159] ) paints a fascinating canvas concerning the number of students and practitioners of mathematical sciences (some contemporaries referred to roughly

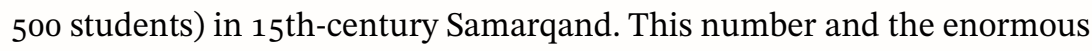
quantity of manuscripts that survived are testimony to how entrenched a scientific education was within Islamic society. Roughly 120 authors wrote 
some 489 treatises during the long 15 th century. Their works are represented by several thousand extant manuscripts located throughout the world. The subject matter of these works was both theoretical and practical astronomy, and it included cosmology (both celestial and terrestrial realms), instruments, handbooks, tables, calendars, timekeeping, and astrology. S. Ragep focuses in particular on theoretical astronomy, i.e., the tradition of hay a. Works in this tradition belonged to a genre of astronomical literature termed 'ilm al-Hay'a, which attempted to explain the configuration ( $h a y^{\prime} a$ ) or physical structure of the universe as a coherent whole; thus, for celestial bodies, it included cosmography and for terrestrial bodies, geography. This tradition brought into a single discipline the unchanging celestial realm of aether and the ever-changing realm of the four elements, the world of generation and corruption. This tradition can be traced back to the 11 th century when the term «hay'a» was adopted, particularly in eastern Islam, as the general term for the discipline of astronomy which did not include astrology. The hay'a basița literature was influenced by Ptolemy's Almagest (omitting its mathematical proofs) and by his Planetary Hypotheses, and usually included discussions of the sizes and distances of the stars and planets. The main emphasis of the hay ${ }^{3}$-tradition was on translating mathematical models of celestial motion into a bodily representation in order to show the configuration (hay'a) of the universe as a whole. It focused on external aspects of cosmology, on issues related to how the celestial and terrestrial realms operate, not on questions as to why.

Another tradition of Islamic astronomy provided a range of accounts of various aspects of Ptolemaic spherical astronomy and planetary theory. It reworked Ptolemy's Almagest and sometimes included original material, such as there is in Ṭūsī's Taḥrīr al-Majisțī (Recension of the Almagest) as well as treatises devoted to criticizing and reconciling inconsistencies in Ptolemaic astronomy and to reforming certain models, such as Abū 'Alī al-Hasan ibn al-Haytham's al-Maqāla fi hay'at al-'âlam (Treatise on the Configuration of the World). This treatise attempts to explain how the various components of the Ptolemaic models worked and ultimately fit together. It strives to match the mathematical models of the Almagest with physical structures in order to explain the various motions of the celestial bodies.

From these and other examples, it is clear that Islamic astronomy in the $15^{\text {th }}$ century was not an isolated event or episode but was built upon centuries of scientific work. This was also the astronomy "that most likely provided the immediate context of transmission to a bourgeoning European astronomy" 
[156] through the institutions of the Ottoman Empire. It is, as S. Ragep affirms, "through these Ottoman institutions that one finds the connection between Islamic astronomy, Copernicus, and his immediate Latin predecessors" [156]. A certain Moses ben Judah Galeano (Mūsā Jālīnūs), the subject of the final chapter of Before Copernicus by Robert Morrison, was especially important in this transmission: he traveled, among other places, between the Ottoman court and Italy.

The last question posed by S. Ragep is why Islam, despite thriving scientific traditions and stunning achievements in astronomy, did not give rise to a Copernicus. She claims that the reason lies exactly in these traditions:

Scientific change may be far more difficult when the traditions...are so entrenched....Thus, paradoxically, the strength of a scientific tradition, such as that in Samarqand, may have been a hindrance to adopting new, revolutionary ideas. Perhaps the lesson we then take from this cross-cultural comparison is that proposing revolutionary ideas may be easier for someone, such as Copernicus, whose scientific context was less rigid and was, in many ways, a work in progress. [158]

F. Jamil Ragep ("From Tūn to Toruń: The Twists and Turns of the Țūsī-Couple" $[161-214]$ ) takes up the case of the transmission of arguably the most famous astronomical device of Islamic astronomy, the so-called Țūīi-couple, which was invented by Nașīr al-Dīn al-Ṭūsì (d. 1274) to amend Ptolemy's use of the equant. The Țūî̀-couple is actually not a single device or model but a general concept that encompasses several different mathematical devices serving different purposes. There are several versions:

(1) the mathematical rectilinear version, which consists of two uniformly rotating circles that can produce oscillating straight-line motion in a plane between two points;

(a) a physicalized version of (1);

(2) the two-equal-circle version, which is a curvilinear version meant to produce a linear oscillation on a great circle;

(3) the three-sphere curvilinear version, consisting of three additional orbs enclosing the epicycle that are meant to produce a curvilinear oscillation that results in motion in latitude; and

(a) the two-sphere curvilinear version, which is a truncated version of the full three-sphere curvilinear version.

Țūsī elaborated different versions of the device at different stages of his career and used them to solve different technical problems. The first one and its physicalized version, for example, were used with the aim of replacing 
the equant in planetary models. The second one was meant to account for Ptolemaic motions requiring a curvilinear oscillation on a great circle.

Within the Islamic context, the Țūsì-couple was subject to further development and discussion over many centuries. Since there are no translations of Țūsìs writings on the couple in non-Islamicate languages, J. Ragep postulates transmission though non-extant texts and/or non-textual transmission and thus bases his case "on plausibility rather than direct evidence" [174]. He argues, given the various types of evidence of transmission, that "independent rediscovery, especially multiple times, becomes much less compelling" [175].

There were several appearances of the Țūsī-couple outside Islamic societies. The first occurred in Byzantium around 1300. It is found in the work of a certain Gregory Chioniades of Constantinople, the translator of a number of astronomical treatises from Persian (or perhaps Arabic) into Greek. One of them, which is dubbed The Schemata of the Stars, uses the Tūìi-couple in the lunar model and thus seems to derive from Țūsı's earlier Persian (not Arabic) works.

[T]here can be no question that some of Țūsìs innovations had made their way into Greek by the early fourteenth century, and the existence in Italy of the only three known manuscript witnesses strongly suggests that the transmission of this knowledge had made it into the Latin world by the fifteenth century. [176]

In Latin Europe, the Tūisi-couple appeared several times-the first was in the 14th century. Here follows a list of authors in whose works it can be found: Avner de Burgos, Nicole Oresme, Joseph ibn Naḥmias, Georg Peurbach, Johann Werner, Giovanni Battista Amico, and Girolamo Fracastoro (Homocentrica, 1538), who refers to a device for producing rectilinear motion but does not incorporate it into his astronomy.

Copernicus used the Țūsī-couple in both his Commentariolus and his De revolutionibus. In the Commentariolus, he used the truncated two-sphere curvilinear version for the latitude models and the physicalized rectilinear version to vary the radius of Mercury's orbit, but in a truncated, two-sphere version without the enclosing/maintaining sphere. It seems, J. Ragep assesses,

that Copernicus was attempting to provide actual spherical models for the two versions of the Tuusī-couple he uses in the Commentariolus but that he cut a corner or two by not dealing with the disruption of the contained orb. [184]

In De revolutionibus, Copernicus relies only on the two-equal-circle version, which is a mathematical, not a physical, model. 
Although it seems that the majority of historians of early astronomy have accepted to a lesser or greater degree the influence of late-Islamic astronomy on early modern astronomers, particularly Copernicus, there are some (Di Bono and Goddu, for instance) who demand more evidence of transmission. In order to provide such evidence, J. Ragep summarizes the past 25 years on the issue. Dealing first with the critics of transmission (Veselovsky, Di Bono, Goddu), he then provides empirical evidence of transmission.

There is evidence that the Țūsì-couple first made its way into another cultural context through Byzantine intermediaries, first and foremost through Gregory Chioniades. This transmission occurred through an adapted translation from Persian into Greek. The circumstances under which Gregory's Schemata itself was further transmitted are less clear. The Schemata is currently witnessed by three manuscripts: two in the Vatican and one at the Biblioteca Medicea Laurenziana in Florence. These sources provide evidence that the work, with diagrams, was available in Italy as early as 1475 . Swerdlow and Neugebauer favor this Italian route for the transmission of the Țūsīcouple to Copernicus. Since Copernicus spent part of the Jubilee year 1500 in Rome, this opens up the possibility that he had access to the Schemata. There may also have been another channel of transmission-the Spanish connection-which could have brought the new astronomy of 13th-century Iran to the Latin West. There was considerable ongoing diplomatic activity between the Spanish court of Alfonso X of Castile and the Mongol İlkhānid rulers of Iran.

And there is yet another possibility, the Jewish link. Tzvi Langermann and Robert Morrison have shed light on a host of personalities involved in the transmission of astronomical models from Islam to Christendom through Jewish scientists and mathematicians. Langermann has shown that in 15thcentury Italy, Mordecai Finzi knew the Meyashsher aqov of Avner de Burgos, in which it is proved that a continuous straight-line oscillation could be produced by means of a Țūsi-couple. That Finzi knew of the Meyashsher 'aqov is indicated by his copying of some interesting technical details in Avner's text. It seems reasonable to assume, as J. Ragep claims, that Finzi "knew the other parts of the Meyashsher 'aqov, including the Țūsì-couple proof" [190]. Finzi also had extensive contacts with Christians. Finzi is an example of "a Jewish scholar who most likely knew of the Țūsi-couple in contact with north Italian mathematicians a generation or so before Copernicus would be in the neighborhood" [190]. 
The last piece of empirical evidence of transmission discussed by J. Ragep is the sheer number of the manuscripts containing one or other of the versions of the Tūsī-couple. In this context, it is significant

that the critical proposition that Swerdlow has claimed was used by Copernicus to transform the epicyclic models of Mercury and Venus into eccentric models, which is found in Regiomontanus' Epitome of the Almagest, was put forth earlier in the 15th century by 'Alī Qushjī of Samarqand. [191]

It is not known how Qushjīs treatise came to be known by Regiomontanus but a very likely candidate for transmitter is Cardinal Basilios Bessarion.

Robert Morrison ("Jews as Scientific Intermediaries in the European Renaissance" [198-214] ) takes up the role of Jews in the circulation of scientific knowledge. Morrison argues against a solely European context for Copernicus' work and discusses the criticism and modifications of Ptolemaic astronomy in both Renaissance Europe and Islamic societies, and how Copernicus could have learned of the achievements of astronomers from Islamic societies. The focus of the chapter is the Tūìi-couple and how a text in astronomy, The Light of the World, which was written by the Jewish astronomer Joseph ibn Nahmias (fl. ca 1400) and composed in Judaeo-Arabic (a dialect of Jews in the Arabic-speaking world), and a recension of it written in Hebrew characters, could have interested Renaissance astronomers.

Morrison points out several parallels between The Light of the World, an attempt to improve Nūr al-Dīn al-Bitrūjī’s (fl. 1200) Kitāb fì al-Hay’a (On the Principles of Astronomy), which was translated into Latin by Michael the Scot, and the works of early modern European astronomers interested in the revival of homocentric astronomy. Nahmia supposes that all celestial motions occur on the surface of an orb and accounts for these motions by means of a set of homocentric orbs with the Earth at the precise center of that orb or set of orbs. His models improved on the predictive accuracy of Bițūjî̀s models, although not completely. Regiomontanus and other Renaissance astronomers, working and/or interested in the tradition of homocentric astronomy, would certainly be interested in his models due to their philosophical consistency. Since there is no evidence of the presence of theories from The Light of the World in the Veneto as early as 1460, Morrison agrees with Swerdlow that-despite certain similarities between Regiomontanus' homocentric models and the Hebrew recension of The Light of the World-it did not influence Regiomontanus..

One of the interesting technical features of The Light of the World, adopted in the Hebrew, is the improvement of the reciprocation mechanism. In addition to this development of the mechanism for reciprocal motion, both the Arabic 
and Hebrew versions contain another hypothesis that is mathematically equivalent to the curvilinear version of the Ṭūsī-couple in Țūsì's al-Tadhkira $f_{i}{ }^{\prime} i l m$ al-Hay'a. They both suggest the elimination of the circle of the path of the center and the inclined circle carrying the circle of the path of the center from the solar model. This is the model that appeared in Giovanni Battista Amico's (d. 1538) De motibus corporum coelestium, written in the 1530 in Padua. Another reviver of homocentric astronomy, Fracastoro, referred to the double-circle hypothesis but did not incorporate it into his astronomy. There is a real possibility that Amico and Fracastoro could have learned of the double-circle hypothesis from The Light of the World.

Morrison continues by presenting specific connections between Islamic, Jewish, and European scholars and routes by which Jews became intermediaries between Islamic astronomers and European Renaissance intellectuals. Morrison focuses on two possible channels. One of the possible mediators, probably the key one, was Moses ben Judah Galeano (Mūsā Jālīnūs, d. after 1542), who was present at the court of the Ottoman Sultan Bāyazīd II (1481-1512) in Istanbul. Galeano composed a Hebrew text entitled Ta 'alumot hokmah (Puzzles of Wisdom) around 1500 and finalized it in the 1530 . $\mathrm{Ta}$ 'alumot ḩokmah mentions the astronomy of 'Alā' al-Dīn ibn al-Shātị, whose models figure extensively in Copernicus' work and explains that The Light of the World was a text about homocentric astronomy. It also describes Galeano's visit to Venice around 1500, during which he met with the prominent printer Gershom Soncino. Another possible route for the passage of The Light of the World was from al-Andalus to Istanbul and from there to Padua. Linguistic evidence suggests that Galeano's own text on homocentric astronomy found in the Topkapi Library was translated from Hebrew or transcribed from Judaeo-Arabic. It is, therefore, plausible that the extant Arabic text by Galeano is a translation or transcription carried out in Istanbul of a now lost Hebrew or Judaeo-Arabic version of The Light of the World, which was probably made before Galeano left Istanbul for Venice. In any case, the contents of The Light of the World, if not the complete manuscript, clearly found their way to Istanbul.

The striking parallels between Ibn Nahmias' theories and those of the astronomers in Padua, Galeano's voyage to Venice, and the much later report of The Light of the World's being at Padua make it highly likely that scholars at Padua such as Amico and Fracastoro were aware of the contents of The Light of the World. The career of Moses ben Judah Galeano helps to explain the numerous parallels with Ibn al-Shātị's theories in Copernicus' work. 
Another question regarding scholarly exchange is whether any Jews knew what contemporary European Renaissance astronomers were doing. As proven by translations of Averroes' (Ibn Rushd's) corpus into Latin, there was an area of contact between Jews and Christians in Europe: Jews translated three-fourths of Averroes' writings into Latin from Hebrew translations of the original Arabic. Furthermore, there is some evidence that the last Jewish Averroist, Elijah Delmedigo (d. 1493), knew of recent efforts to develop new theories in astronomy. While his commentaries on Averroes' Latin Metaphysics and on his On the Substance of the Celestial Orb do not refer explicitly to Ibn Naḥmias or even to Bițrūjī's work, Delmedigo's Hebrew commentary On the Substance of the Celestial Orb makes "a clear connection between the dismissal of eccentrics and epicycles and Renaissance Averroism's interest in the physical world" [210]. In the same commentary, Delmedigo also makes a reference to attempts to reform Ptolemaic astronomy in the face of the familiar Averroist criticism that Ptolemy's eccentrics and epicyclic orbs contradict the roots of natural science. He complains that some later astronomers were trying to save Ptolemy by positing bodies without any function except for filling the void. Morrison suggests that Delmedigo here refers to Ibn al-Haytham or Jābir ibn Aflah, critics of Ptolemy, cited in Ibn Rushd's Talkhīṣ al-Majisțī. Since Delmedigo's manuscript was probably composed in 1485 and copied in 1492, that is, before Delmedigo returned from Italy to Crete, it is possible that "the attempts to save Ptolemy to which Delmedigo referred were attempts by European astronomers such as Regiomontanus, not the work of recent Islamic astronomers" [211]. This would provide evidence

that a prominent Jewish scholar may well have known of developments in 15th century European astronomy, providing more indications that Galeano would have known that there were European astronomers interested in the news he was bringing from the Ottoman Empire, and/or it is evidence that another Jewish scholar in Galeano's milieu knew about important achievements in Islamic astronomy. [211]

But even if the referent were earlier critics of Ptolemy, this text would have alerted the reader to the interest of scholars in Europe (which is where Delmedigo was writing) in models based on perfectly homocentric orbs as solutions to the known problems of Ptolemaic astronomy. The role of Jews from both Andalusia and the Ottoman Empire in the scholarly exchanges is also evident from their role in the composition of astronomical tables. 


\section{Critical assessment}

Before Copernicus is a rich book in terms of both scope and depth. ${ }^{3}$ The result of a project extending more than 15 years and four workshops held at different academic institutions, the book brings together eight chapters written by some of the leading experts in the field who can claim a substantial number of important publications. Most of the chapters, if not all, make very handy summaries of the previous research and publications by the authors and other scholars, adding at the same time fresh and nuanced details and insights. Many chapters are illustrated by very useful tables, diagrams, and images. No summary, no matter how extensive, can do complete justice to the wealth of detail, technical and historical nuance, and profound analysis based on a close examination of the vast number of primary sources, while keeping the results of previous research in mind.

In general, I consider the following to be the major strengths of Before Copernicus. The first is its very topic: before Copernicus. There had been, despite significant previous research and publication, a need for a comprehensive and up-to-date reexamination of the numerous topics that focus on the immediate and less immediate contexts of Copernicus. We now have a general overview of the basic features of the long 15th century and European attitudes toward the Islamic world as well as a handy and comprehensive study of:

o the development of physical astronomy and different concepts of astronomy as a science during the Middle Ages and Renaissance;

- Regiomontanus' approaches to astronomy and his impact on Copernicus, an intriguing chapter on the different conceptualizations of appearances and their "beyond";

- Islamic mathematical scholarship in Samarqand and elsewhere;

- the Ṭūsī-couple and its possible transmission channels; and finally

- the role of Jews as scientific intermediaries.

The second is the book's collaborative nature. Authors with different preoccupations, specialists in their own areas of pre-Copernican and Copernican scholarship, concentrate on clearly defined topics (the social and intellectual background to Copernicus' Commentariolus). Due to the complexity and enormous range of the issues, this is-as I have experienced myself-hardly a task for one person.

3 All critical remarks and suggestions that follow are based on my research on Copernicus and his context, which was published in Vesel 2014. 
Its third is its "multicultural" approach. Although the influence of Islamic astronomy on the Latin West, including Copernicus, has been known and widely acknowledged, some scholars still doubt it, especially when it comes to Copernicus. Copernican astronomy is even nowadays sometimes-completely anachronistically and perhaps also ideologically, to use a mild wordsupposed to be a pure European achievement. "They", the "others", allegedly have nothing to do with his genius. Opposition to such an attitude runs the risk, though, of making Copernicus more indebted to Islamic astronomy than he really was. Putting aside J. Ragep's brief reference to Islamic discussions on the motion of the Earth [see note 3 above], his chapter and the others that discuss the Islamic influence on Copernicus avoid this pitfall.

Its fourth is its multidisciplinary approach. On several occasions, Feldhay and Ragep in their introduction and Feldhay and Chen-Moriss in their chapter make it clear that Copernicus' heliocentric cosmology was not achieved by a purely technical route. There is, as Feldhay and Ragep put it nicely, "more to this monumental cosmological shift [i.e., from a geocentric to a heliocentric cosmos] than a strictly mathematical/astronomical explanation" [4].

With that said, let me now address the question, Does the book explain the nature of Copernicus' Commentariolus and his work in general? I believe it does-but only to a certain extent. It leaves out, unfortunately, some of its essential aspects. If the social and intellectual background that shaped the astronomy and cosmology of the Commentariolus (and consequently De revolutionibus) are to be understood correctly, many issues that should be addressed are either missing or not adequately treated in this volume. These issues range from the treatment of Copernicus' studies and his work after his final return home from Italy to more theoretical reflections on what Copernicus actually says in the Commentariolus, which was, I believe, to a large extent a result of his years in Italy and his work after he returned home. Before Copernicus treats his Italian years and what he had learnedthe possibilities that had opened up for him there-very superficially. Its focus is mainly on his years in Cracow and, within this framework, only Aristotelian influences are taken into account. A more theoretical problem is that the Commentariolus is treated very selectively. When it is cited and discussed, many nuances are overlooked. One would like to understand specifically how Copernicus' context is linked to his text(s). Let me illustrate my reservations by following the structure of the book, starting with the introduction. 
I find the last five observations, numbers (3) to (7) [see pp. 76-77 above], and the conclusions reached therefrom to be more or less sound. I also very much agree with Feldhay and Ragep that Swerdlow's technical reconstruction of Copernicus' conversion to heliocentrism is not conclusive. I have, however, some reservations about "observations" (1) and (2) regarding the principle of uniform motion and the absence of the symmetria-argument stated in the Commentariolus and the conclusion(s) that they derive from them. It is of course indisputable that Copernicus' first stated purpose in the Commentariolus is, to put it briefly, to satisfy the principle of perfect, uniform, and circular motion. It is also true that Copernicus here does not refer explicitly to the "marvelous symmetry" of the world. But it is not clear to me what exactly is the point of the editors' conclusion(s) reached from numbers (1) and (2) [see p. 77 above], i.e., that Copernicus' initial motivation was the equant problem and that the justification from the symmetria ${ }^{4}$ achieved by a heliocentric cosmology was post hoc and that, as a consequence, it did not play a motivating role. Motivation to do what? To start working on the problems of Ptolemaic astronomy? To reform astronomy in such a way that it would be brought into line with the principle of uniform, circular movement? To reform it along heliocentric and geokinetic lines? Or something else?

It could well be that Copernicus was primarily moved to tackle the reform of Ptolemaic astronomy by "irregularities" contravening the principle of circular uniform motion. Or by any other "irregularity" that he might have learned of from the astronomical literature at his disposal. It is completely plausible and reasonable. But if that alone were the case, Copernicus would have stayed within a reformed geocentric system. As Feldhay and Ragep nicely explain, this

would have secured his fame, earned him the gratitude and admiration of his contemporaries and successors, and spared him and those successors a considerable amount of grief. [7]

Copernicus does not rest with a reformed geocentric cosmos, however. Just a few paragraphs after his complaint about these "irregularities" and after he lists seven (heliocentric) petitiones, he argues for the order of the cosmos on the basis of the so-called distance-period principle [see Goldstein 2002], the same principle that he also uses in his mature De revolutionibus, where he claims that in this way a marvelous symmetria (or harmonia) of the world is achieved. In the heliocentric order of the spheres, Copernicus affirms in the Commentariolus that "one [planet] exceeds another in rapidity of revolution

\footnotetext{
${ }^{4}$ Note that Copernicus used Greek in his De revolutionibus.
} 
in the same order in which they traverse the larger or smaller perimeters of [their] circles" [Swerdlow 1973, 440]. Saturn makes its period in 30 years; Jupiter, in 12; Mars, in two, while Earth has a one-year period; Venus, nine months; and Mercury, three months. The only difference between the De revolutionibus and the Commentariolus is that in the latter Copernicus does not explicitly mention symmetria (or harmonia). But the principle and the results of that principle are already there. Thus, the ordering of the planetary spheres was, then, an important motivating consideration already in the Commentariolus. So, if the aim of the book is to render the Commentariolus understandable, it should not avoid discussing this issue. But, as it stands, this essential feature is left unaddressed.

The question, as I see it, is, therefore, What connects the issue of the principle of perfect motion and, as it was subsequently called, the harmonious order of the planets? Since Copernicus did not arrive at heliocentrism by a technical route, linearly, so to speak, from the equant problem to the problem of the forma mundi, there must be some conceptual common denominator of both issues. What exactly is the "more" from Feldhay and Ragep's claim that there must be "more to this monumental cosmological shift than a strictly mathematical/astronomical explanation"? Which aspects of his "intellectual and cultural context...led him to his decision to put the Earth in motion"? [6-7].

2.1 On part 1 While the first two chapters depict some of the matters that could be relevant to Copernicus, they remain on a very general level and are, in my view, of relatively limited use for understanding his specific astronomical and cosmological enterprise. Bisaha provides some possible explanations of Copernicus' silence as to his Islamic sources, among which the "innocent omission at some point in the transmission" seems the most appealing to me. Celenza in his turn does mention Copernicus' study at the Universities of Bologna and Padua but devotes very little attention, almost none, to the curricula there. He does not say anything about the books that Copernicus purchased at the time and there is nothing on the people with whom he may have discussed burning astronomical and astrological questions (the astrological "crisis") [see Westman 2013, 76-105]. Moreover, there is nothing about Copernicus' learning the Greek language nor about his visit to Rome where he may have had access to Bessarion's library (mentioned by J. Ragep), and so on. In Padua, for instance, Copernicus very probably learned Greek with Nicholas Leonicus Tomaeus, an acquaintance of Callimachus (they met in Venice in 1486), who was very active in Cracow. Tomaeus read Plato in Greek at the University of Padua from 1497 to 1506 and translated a portion of Plato's Timaeus 35a-36e along with Proclus' commentary on the 
same passage. Girolamo Fracastoro, author of the Homocentrica (1538), who was in Padua at about the same time as Copernicus, first as a student and then as a teacher of logic, reported that the homocentric revival initiated by Giambattista Della Torre was somehow related to Plato's Timaeus. In his dedication to Pope Paul III in the Homocentrica, he explains that Della Torre, on his deathbed, told him to recall the circles from the Timaeus in the shape of the letter X [Fracastoro 1538, "Sanctissimo Pavlo Pontifici Maximo"]. Fracastoro refers here to Timaeus $36 \mathrm{~b}-\mathrm{c}$, which is included in the part translated by Leonicus Tomaeus.

2.2 On part 2 This neglect of Copernicus' student years is partly amended by Sylla's chapter. She thoroughly discusses three important books of two of the most remarkable teachers of Cracow, both with interests outside astronomy, and sets them in a broader context. Her discussion of the history of physical astronomy in the long period from Ibn al-Haytham through the Middle Ages to Copernicus' years in Cracow, and of the status of astronomy as a science as debated by antiqui and moderni as well as in the three texts by Głogów and Brudzewo, is very thorough, interesting, and useful. One becomes aware of many matters previously unknown or known only partially. Among many useful insights, I would point out Brudzewo's understanding of the equant as mathematical (hence, imaginary) and not as physical. There are several problems, though, which I see in her account. The first two are more general in nature but with important consequences for understanding the Commentariolus (and De revolutionibus). She limits her discussion to Copernicus' studies in Cracow and makes several remarks that at least imply—if not directly affirm — that those years constitute the decisive background to his Commentariolus. What about his subsequent studies in Bologna and Padua? Did they not contribute anything to the genesis of the Commentariolus? And what did Copernicus do after he returned to Warmia but before he wrote the Commentariolus?

Sylla also directs her attention only to the Aristotelian tradition and completely ignores the humanist and Platonist current(s) of Cracow's intellectual life. This is strange since there is plenty of evidence thereof. Filippo Buonaccorsi, called Callimachus Experiens (1437-1496), as already mentioned, was very active in Cracow. He corresponded with the Platonist and translator of Plato's Opera omnia, Marsilio Ficino (1433-1499), who called Callimachus "my fellow Platonist". Callimachus was constantly traveling from Cracow to Italy and Constantinople. In 1485, one of Cracow University's reading rooms was called Plato's and Albert of Brudzewo was mentioned in that connection. Even John of Glogów, who appears to have mostly 
drawn on the Aristotelian tradition, was well versed in other philosophical schools of thought, including Plato and Platonism. In his manuscript In metaphysicam (or Quaestiones super duodecim libros metaphysicae Aristotelis), to give just one example, he mentions Plato approvingly several times. While in Cracow, Copernicus was also closely connected with Laurentius Raabe Corvinus, another Platonist, one of the most important members of the Cracow's humanist Vistulan Literary Sodality. After Copernicus' return from Italy, Corvinus helped him publish his Latin translation of Theophylactus Symocatta's Greek Epistolae morales, rurales et amatoriae.

There is no doubt in my mind that Copernicus (and those of his contemporaries who read it) understood Commentariolus as a theorica. It is a theoretical astronomy, using physical astronomy (the three-orb compromise) and partly mathematical astronomy. It also fits quite nicely into the practice of some theoricas by establishing some physical principles on which the subsequent astronomy is based. According to Sylla, Copernicus mirrors these physical principles with his petitiones; namely, Copernicus claims that he could solve the problem "if some postulates, called axioms (petitiones quas axiomata vocant) are granted to us" [Swerdlow 1973, 436]. Sylla calls these petitiones hypotheses or principles, puts them on a par with scholastic suppositions, principles, or premises, and claims that they are "derived from experience" [49]. She also claims that in the Commentariolus these principles are stated postulates (petitiones), while in Peurbach's Theoricae novae they are the theoricae (figures) themselves.

Despite some similarity between the Commentariolus and Brudzewo's Commentary on Theoricae novae in the matter of the physical principles, I believe that an epistemological distinction is in order. Copernicus' postulates or axioms are neither derived from experience nor have exactly the same epistemological status as suppositions, principles, or premises. How, for instance, can the fifth postulate-

Whatever motion appears in the sphere of the fixed stars belongs not to it but to the earth. Thus the entire earth along with the nearby elements rotates with a daily motion on its fixed poles while the sphere of the fixed stars remains immovable and the outermost heaven. [Swerdlow 1973, 463]

-be derived from experience? And if it were-let us allow this for the sake of the argument-from which experiences or observations exactly? There are approximately 70 documented observations by Copernicus, and he occasionally does refer to observations and measurements of the positions of the stars from which ancient philosophers worked out their planetary theory. But I am not aware of any instance when he did so in reference to himself. 
As noted by Shank, Copernicus was "following Regiomontanus in not undertaking to derive his astronomical models themselves from observations" [108]. It would be very useful to make a list of all of his observations and analyze them to determine what precise purposes he had in using them. I also do not understand how the statement of principles in the Commentariolus can mirror-this time, specifically-that in Peuerbach's Theoricae novae. Why would Brudzewo need to "establish" principles in his commentary, as Sylla claims he did [53], if they were already established by Peurbach himself (figures/theoricae)?

I believe that the key to the secret of Copernicus' axioms or postulates is to be found elsewhere and that it is Copernicus himself who reveals where. In one of his annotations to Plato's Parmenides in Ficino's translation, he writes "what needs to be known about hypotheses (quid aduerti oporteat circa hypotheses)". Copernicus obviously understood hypotheses, axioms, and postulates in Platonist terms. This is further confirmed when we compare the Commentariolus and Proclus' Commentary on Plato's Timaeus 2.3. In this passage, Proclus explains that Plato is not an empiricist: Plato does not start with experiences and then draw conclusions. Plato's method ( $\mu \varepsilon \theta_{0} \mathrm{o}-$ $\delta o \varsigma)$ is hypothetical or, rather, Plato uses the method of hypothesis. He sets out fundamental axioms ( $\dot{\alpha} \xi \mid \omega ́ \mu \alpha \tau \alpha)$ and hypotheses ( $\dot{\pi} \pi 0 \theta \dot{\varepsilon} \sigma \varepsilon 1 \varsigma)$ and draws conclusions. Proclus first presents a list of five axioms and then follows with another list of seven. Describing Plato's "hypothetical method", Proclus does not refer to Plato's own description of the hypothetical method but explicitly refers to the method used by geometers. They first postulate, define, and name their key principles before proceeding to their demonstrations. And he cites an example from Euclid. On the basis of fundamental principles or hypotheses, Plato's Timaeus then proceeds, in Proclus' reading of the text,

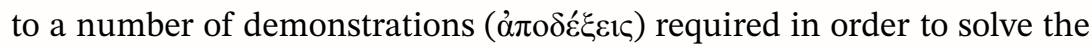
problems. Copernicus' method in the Commentariolus is highly reminiscent of Proclus: he first establishes seven petitiones quas axiomata vocant and then promises to provide mathematical demonstrationes in a larger book. I find Shank's chapter to be one of the highlights of Before Copernicus. In a very well written, exciting exposition, Shank depicts the interrelatedness of seemingly unrelated issues-astronomical (the controversy regarding Ptolemy's Almagest), religious, and political (the Crusades, Orthodox/Roman Catholic Christianity) - that played a part in the life and work of Regiomontanus, the most advanced astronomer before Copernicus. From his exposition, it is abundantly clear that Copernicus was working not in a void but in a period of vigorous institutional development in astronomy that was 
to a large extent due to Regiomontanus' work and his printing activities, themselves in turn the result of long and multifaceted dispute. The main characteristic of Regiomontanus' work is its search for a philosophically (i.e., physically) adequate astronomy. He also makes it clear why Regiomontanus was justly considered the most advanced astronomer in the second half of the $15^{\text {th }}$ century as well as to what extent and regarding what particular details Copernicus relied on and used his work.

I have only one remark here. Shank complains that while intellectual historians are familiar with George of Trebizond's attacks on Plato and Cardinal Bessarion's defense of the latter, "the astronomical and astrological dimensions of that conflict are poorly integrated into the history of astronomy" [87]. As are, I would like to add, the philosophical dimensions. What do I mean? Copernicus bought and annotated a book by Cardinal Bessarion, In calumniatorem Platonis, in which he read praise of Plato as a mathematician. In book 4, chapter 12, for example, Bessarion defends Plato against the accusation that mathematics was to be taught to those who wanted to become divine. He declares that, according to Plato, mathematics was truly the subject most worthy of study by a free man and continues, paraphrasing the Epinomis, that the easiest way to ascend to the divine was through mathematics. He concludes the chapter by referring the reader to books 7 and 10 of the Laws, to the Epinomis, as well as to books 5, 6, and 7 of the Republic. This is relevant to the question addressed by Chen-Morris and Feldhay: How did Copernicus end up going "beyond the appearances"? While this is the right question, however, their answer, I am afraid, is not correct. I share with them numerous epistemological conclusions about Copernicus' work. I strongly agree that Swerdlow's reconstruction of Copernicus' path to heliocentrism is not satisfactory and I also agree that we should ponder the question of the relationship of appearances to their "beyond". In this context, Copernicus' astronomy questions the role of vision in the cognitive process leading to knowledge, which has special relevance to the epistemological status of astronomy. The very essence of Copernicus' argument is to limit vision and surpass it. Copernicus transcends visual experience and establishes a new point of view, whence a new picture of the universe is revealed. But I fail to see how any connection between these insights with Alberti's artificial perspective and Cusanus' theological speculations can be established.

It is Plato who demanded, specifically in reference to study of the heavenly motions, that astronomy should go beyond the visible motions of the corporeal universe. Plato makes this demand in the Timaeus and he is 
especially clear about it in the Republic $7.528 \mathrm{e}-530 \mathrm{c}$. There, he instructs that astronomy must be learned differently from the way in which it is learned at present. We should consider the ornaments in the heavens as the best and most exact visible things. But we should at the same time admit that these motions fall short of the true ones:

those motions which the real speed and the real slowness in [their] true numbers and in all [their] true figures move relatively to each other and carry along whatever is in them, these things are for reason and understanding, not for sight, to discern. [Vlastos 1980, 2]

The decorations in the heavens are just models, an excellent starting point to discover the real movements of the stars, but not by any means their real motions. It is just as if someone came upon some thoroughly well-drawn and perfected diagrams of some skilled craftsman or artist, such as Daedalus. He or she would consider them beautifully crafted but would "think it laughable to scrutinize them zealously, expecting to find in them true equality or duplicity or any other relation of symmetria" [Resp. 529e-530a: Vlastos 1980, 3 lightly modified]. The True Astronomer would feel the same when looking at the motions of the stars. He would find the tracings beautiful but it would be absurd for him to seek to obtain the truth "of the relation of [the] symmetria of night to day, of these to months, and of the [periods of the other] stars to these and to one another from the visible appearances" [Vlastos 1980, 3 lightly modified]. According to Alexander Mourelatos, the Real Astronomer "does not dismiss questions concerning the symmetria of celestial periods" $[1980,39]$. On the contrary, Plato demands that the True or Real Astronomer discovers the true symmetriai-that is, the commensurable proportions-of celestial periods, which exist beyond visible motions; the Real Astronomer "realizes that the aletheia concerning these symmetriai cannot be elicited from the observed periods of the celestial bodies" [Mourelatos 1980, 39].

2.3 On part 3 I find S. Ragep's chapter very informative and well documented. The extent of mathematical scholarship and the technical innovations of Samarqand and the other astronomers that she depicts is impressive. I also like her more general warning about the "danger of putting forth explanations based on the heroic individual scientist in search of knowledge" [156]. The same goes for Morrison's chapter. I think that it shows convincingly the possible passages of Islamic astronomy through Jewish scholars. J. Ragep's chapter, another highlight of the book, clearly explains the concept and development of the Țūsī-couple and discusses channels through which it could have been brought, together with other Islamic materials, to Latin Europe and to Copernicus. Given all the evidence of transmission, I 
think it safe to agree with J. Ragep that independent rediscovery of all these materials, especially many times, is much less compelling.

All I should like to add regarding the third part of the book are some other possibilities for the transmission of Islamic astronomy to the Latin West. First, it seems to me that Bessarion's legacy, which includes his own books as well as the books and manuscripts of his library, deserves fuller and much more thorough research. I have already mentioned his In calumniatorem Platonis and its impact on Copernicus; but the books included in his library, those mentioned by Shank and cited above (by Proclus, Theon of Alexandria, and Theon of Smyrna) as well as possibly many others, should be read with renewed interest. The same goes for the manuscripts that he brought with him. Next, Callimachus was constantly traveling from Cracow to Constantinople and Italy (Venice, Rome, Padua, and Florence). Could he not have brought some materials? Finally, while in Padua, Copernicus lived in the house of Girolamo Della Torre. Della Torre was subsequently praised by Girolamo Fracastoro in his Homocentrica (published in 1538 in Venice) as his inspiration for the revival of homocentric astronomy. Fracastoro, as I mentioned earlier, was in Padua at about the same time as Copernicus and mentions the Țūsī-couple in his book. He studied literature, mathematics, astronomy, and philosophy (the latter under the guidance of Pietro Pomponazzi and Nicholas Leonicus Tomaeus), and received his doctorate in artibus on 2 November 1502. One of his promoters at the conferment ceremony was Gabriele Zerbi (1435-1505), a professor of theoretical medicine and a humanist who discovered several medieval scientific manuscripts and had contacts with the Ottoman Empire. This is, I believe, another possible route deserving of further study.

My closing remark on the topics of transmission: given that the astronomical models in the Commentariolus and De revolutionibus differ rather significantly, it would be good to examine whether Copernicus worked on the basis of one manuscript, one set of manuscripts, or many manuscript or sets of manuscripts. Did he obtain any new material after the Commentariolus, and if yes, how?

\section{Conclusion}

Feldhay and Ragep claim in the introduction that Copernicus' system is a result of many practices

that included attempts to deal, mathematically, with violations of physics found in Ptolemy's models, discussions of the relation between natural philosophy 
and mathematics, and epistemological forays into the "true" cosmology and the human capacity to discover it. [8]

They likewise believe that $15^{\text {th-century astronomy was }}$

the outcome of multiple transformations along different paths that crystallized in the work of Copernicus into some kind of coherent whole that differed enough from the preceding astronomical discourse to open the door to additional, enhanced transformations. [8]

I could not agree more. The question is, however, whether Before Copernicus covers the essential "transformations" that led to Copernicus' work and whether they are treated adequately such that they explain his work as "some kind of coherent whole". It is clear from the reservations and critical comments stated above that I do not believe that is the case. In particular, the issue of the aspects of Copernicus' intellectual and cultural context that led to his decision to put the Earth in motion is, for the reasons given above, not treated adequately.

According to the editors [8-10], three kinds of transformation lie in the background to the Copernican system:

(1) transformations in the body of knowledge;

(2) transformations related to the image and status of astronomy (the older order of the disciplines being more or less accepted in both Islamic and Christian environments for centuries); and

(3) transformations in the paths of the transmission of knowledge, in its carriers and their identities.

In what follows I will use their scheme as a point of departure and suggest some changes that, according to my research, are more appropriate to Copernicus' work.

The first category of transformation concerns the body of knowledge and is subdivided into three subcategories:

(a) the transformation of Ptolemaic two-dimensional circles into physical, three-dimensional orbs, as proposed by many scholars;

(b) new types of models, i.e.,

(i) the transition from the epicyclic models for the second anomaly of the inferior planets to their eccentric models ('Alī Qushjī and Regiomontanus), and

(ii) the Tūisi-couple and the construction of non-Ptolemaic models;

(c) conceptual transformations related to a moving Earth, "new ways of seeing”. 
I think that it can be affirmed without any reasonable doubt that Copernicus' work was a crystallization of the long period of transforming mathematical models into physical ones, and of many transformations within the astronomical models themselves, i.e., the inventions of new types. As is clear from my previous comments, I also agree that something "more" than just a technical/mathematical explanation is needed for Copernicus' affirmation of the invisible motions of the Earth. But this one should be linked not with Alberti's artificial perspective or Cusanus' speculative mathematics but with Plato and a Platonist understanding of astronomy.

This brings us to the transformations within the second category, that of the image and status of astronomy, that is, its place in the order of disciplines:

(a) the transformations of Ptolemy's two-dimensional mathematical circles into a three-dimensional physical astronomy resulted in a discussion about whether astronomy was to be understood as a mathematical science, a physical science, or both;

(b) New categories for classifying the nature of astronomy-theoretical but non-demonstrative astronomy versus demonstrative theoretical astronomy - thus emerged and enhanced reflection about the epistemic status of its procedures and conclusions.

The epistemic status of astronomy was questioned once the empiricalobservational origins of astronomy's "first principles" [was] addressed following the "physicalization" of astronomy by Islamic astronomers. [9]

In the long 15th century there were, of course, discussions about the mathematical versus physical nature of astronomy, and the "physicalization" of astronomy did indeed lead to epistemological reflections on its status and procedures. But these, I would argue, were far from decisive for Copernicus. Copernicus' heliocentric choice did depend on a "new way of seeing", on looking at the celestial appearances "with both eyes", the corporeal eye and the mind's eye. Yet this was a result of the conceptual change in the status and abilities of astronomy and not vice versa. This change also had little to do with the "physicalization" of Ptolemy's mathematical models. The transformation of a mathematical model of a certain planet into a physical theorica had nothing to do with the arrangement of the planets. The order of the planets was strictly speaking not an astronomical problem. One was able to predict the positions of heavenly bodies in geocentric and Copernicus' heliocentric cosmos equally well. The order of the planets was an astrological and natural-philosophical problem, a problem within philosophy especially for Plato and the Platonists. The Platonist understanding 
of the status of astronomy and its goals was radically different from that in the Aristotelian traditions.

And finally, the last category of transformations in the paths of the transmission of this knowledge:

(a) Basilios Bessarion (the new translation of Ptolemy's Almagest from Greek to Latin, the Epitome of the Almagest, his library);

(b) Jews expelled from the Iberian Peninsula who resettled in the eastern Mediterranean and traveled to Istanbul or Italy;

(c) the diffusion of the Configuration of the World and the tradition based on it in medieval Europe; and

(d) the circulation of knowledge within informal, intellectual-artistic circles that associated around a site of knowledge (Bessarion's library in Rome).

There were many possible paths for the transmission of knowledge from the Islamic world to Latin Europe. I have added some new possibilities. But we also should not forget other transmissions of knowledge: those, namely, that were a result of the renewed humanist interest in Plato and Platonism as reflected in the Latin translation and diffusion of Plato's Opera omnia as well as the works of different Platonist and commentators on Plato (including doxographers), in readings of his work in the original Greek, and so on. One can find much of this already in Bessarion's library.

Let me conclude on a positive note. Despite my reservations and critical remarks, I certainly would have benefited from having Before Copernicus at my disposal before writing my own book on Copernicus.

\section{BIBLIOGRAPHY}

Anton, J. 1980. ed. Science and the Sciences in Plato. New York.

Bessarion. 1469. In calumniatorem Platonis libri IV. Rome. See Mohler 1927.

Copernicus. 1543. De revolutionibus orbium coelestium. Nuremberg. See Rosen 1992.

Feldhay, R. and F. J. Ragep. 2017. edd. Before Copernicus: The Cultures and Contexts of Scientific Learning in the Fifteenth Century. Montreal, $\mathrm{PQ} /$ Kingston, ON.

Fracastoro, G. 1538. Homocentrica. Venice. 
Goldstein, B. 2002. "Copernicus and the Origin of His Heliocentric System". Journal for the History of Astronomy 33: 219-235.

Mohler, L. 1927. ed. Kardinal Bessarion als Theologe, Humanist und Staatsmann. Paderborn.

Mourelatos, A. P. D. 1980. “Plato's 'Real Astronomy': Republic VII. 527d531d”. See Anton 1980, 33-73.

Rosen, E. 1992. Copernicus: On the Revolutions. Baltimore, MD/ London, UK.

Swerdlow, N. 1973. "The Derivation and First Draft of Copernicus' Planetary Theory: A Translation of the Commentariolus with Commentary". Proceedings of the American Philosophical Society 67: 423-512.

Vesel, M. 2014. Copernicus: Platonist Astronomer-Philosopher: Cosmic Order, the Movement of the Earth, and the Scientific Revolution. Frankfurt am Main.

Vlastos, G. 1980. "The Role of Observation in Plato's Conception of Astronomy”. See Anton 1980, 1-31.

Westman, R. 2013. The Copernican Question: Prognostication, Skepticism, and Celestial Order. Berkeley, CA/Los Angeles, CA/ London, UK. 